\title{
How to Integrate International Financial Reporting Standards Into Accounting Programs
}

\author{
Robert A. Singer, Lindenwood University, USA
}

\begin{abstract}
It is expected the SEC will require U.S. domestic companies to prepare and file their annual 1OKs in accordance with international financial reporting standards (IFRS) by 2016. Given the probability that the FASB-IASB convergence project (i.e., Norwalk Agreement) will continue subsequent to mandatory adoption, US accounting programs will be inclined to cover the standards in both reporting regimes. Despite the likely prospect of mandatory adoption of IFRS, most US accounting educators have done little to revise their programs, their courses, and their curricula to address the question of how best to incorporate these standards. This paper discusses the pros/cons of three possible approaches in addressing this question: 1) IFRS taught in a standalone course, 2) IFRS taught in all upper-level financial accounting courses, and 3) IFRS taught across the entire accounting curricula. This paper argues in favor of the third alternative since non-accounting business majors will be expected to have a general knowledge of this reporting paradigm, and thus should receive exposure in the introductory courses. Second, if accounting majors obtain exposure to IFRS across the entire accounting curricula, they will obtain a better understanding and appreciation of essential differences between principles and rules based financial reporting systems. Moreover, such exposure across the curricula will allow accounting majors to better evaluate the impact of IFRS vs. US GAAP across the range of accounting disciplines.
\end{abstract}

Keywords: IFRS; US GAAP; Convergence; Accounting Education

\section{INTRODUCTION}

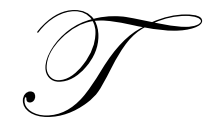

he Securities and Exchange Commission (SEC) is expected to mandate international financial reporting standards (IFRS) for US publicly listed companies by 2016. Wholesale adoption of this financial reporting regime will not happen at once. Rather such adoption will come in stages with implementation varying from company to company depending on the nature, size, and availability of resources. Moreover, it is probable that the FASB-IASB convergence project (i.e., Norwalk Agreement 2002) will continue into the foreseeable future with replacement of US GAAP with IFRS occurring over some specified transition period. It is noteworthy that the SEC has changed the likely adoption date several times. In 2008, it expected to require US-listed companies to file annual 10Ks using IFRS by 2011; in 2009, this date was extended to 2014; and more recently, the implementation date has been extended to 2016. What explains the SEC's reluctance to require US-listed companies to adopt the IFRS regime sooner? A primary reason for the delay in implementation is concern that the various stakeholders, (e.g., creditors, stockholders, and management) will not understand financial statements based on this reporting regime. Relatedly, relatively few US accounting programs have incorporated IFRS in any systematic fashion into their accounting curricula. A survey sent to 535 accounting faculty conducted jointly by the American Accounting Association (AAA) and KPMG LLP found that $62 \%$ had not made any significant effort to incorporate IFRS into their accounting programs. ${ }^{1}$ This lack of effort may be due to a general

\footnotetext{
1 American Accounting Association -KPMG Faculty Survey, University Professors Weigh-In on Building IFRS into the Curricula: Small Number of Universities Will Be Ready for 2008/2009 Academic Year.
} 
unwillingness of faculty to address fundamental change, faculty having little or no exposure to IFRS, time constraints related to existing course coverage, and limited resources due to tight budgets. While the Big 4 international accounting firms have initiated efforts to educate their clients and to make available valuable resources (e.g., webcasts, education materials etc.) to faculty, among others, accounting educators must become more actively engaged in the task of implementing IFRS into their accounting courses. Failure to provide adequate training in this area will render accounting graduates unprepared to understand and analyze financial statements of global companies, most of whom use IFRS. Accordingly, this article examines the pros/cons of alternative approaches toward incorporating IFRS into the accounting curricula. A review of the literature suggests five possible approaches to implementation: 1) as a stand-alone course (e.g., international accounting), 2) included in intermediate and advanced accounting, 3) included only in the intermediate accounting course series, 4) included only in advanced accounting, and 5) included across the accounting curricula. ${ }^{2}$ Approaches 2, 3, and 4 might be combined into one category - included in all upper-division financial accounting courses. Thus, this article considers three approaches for implementing IFRS into the curricula: 1) as a stand-alone course, 2) included in all upperdivision financial accounting courses, and 3) included across the entire accounting curricula.

\section{A STAND-ALONE COURSE}

The advantage of incorporating IFRS into a stand-alone course - say international accounting - is that it is simple and expedient. Given the emphasis placed on globalization and the fact that many accounting programs now offer an international accounting course, it should be relatively easy for an accounting program not currently offering such a course to obtain administrative approval. Second, a faculty assigned to teach the course can readily obtain training in an AICPA sanctioned class and receive an IFRS education certificate. Third, coverage in a standalone course would avoid the the difficulty of having to cover IFRS in an already burdensome intermediate accounting series. The main disadvantage of limiting coverage of IFRS to a stand-alone course is that only accounting majors would be exposed to IFRS. Since a general knowledge of IFRS is important to non-accounting business majors who, as future decision-makers, will have to possess a basic understanding of financial statement and related information based on this reporting regime, the stand-alone approach would not address this need. Another disadvantage of restricting IFRS exposure to a single international accounting course is that students gain a limited appreciation of the essential difference between the principles-based nature of this reporting regime and rules-based US GAAP. Since continued convergence efforts will necessitate consideration of both regimes, the stand-alone course fails to provide students with a more comprehensive and in depth understanding of similarities and differences between IFRS and US GAAP.

\section{INTEGRATION INTO ALL UPPER-DIVISION FINANCIAL ACCOUNTING COURSES}

The second approach would integrate IFRS into all of the upper-division financial accounting courses, particularly intermediate and advanced accounting. The few university accounting programs that have incorporated IFRS into their curricula have limited coverage primarily to intermediate accounting. Since the emphasis of intermediate accounting is on understanding and applying accounting theory, IFRS coverage in this area can be more easily facilitated. In fact, several recent editions of most intermediate accounting texts have integrated IFRS into most of the standard topics - lease accounting, inter-period tax allocation, and stock-based compensation as examples. Application exercises are interspersed between IFRS and US GAAP applications. Some exercises require students to reconcile US GAAP-determined net income and stockholders' equity to that of IFRS. Since the US and IASB conceptual frameworks are similar and coverage of the former, albeit limited, has been included in intermediate accounting textbooks for several years, the IASB Framework, which assumes greater importance under IFRS, can be more easily incorporated into the curricula. Several intermediate accounting texts have interwoven and related the IASB conceptual framework to specific accounting areas involving valuation and measurement of balance sheet elements. Similarly, accounting for mergers and acquisitions - a principal topic of advanced accounting - lends itself well to IFRS coverage. Coverage of IFRS in this accounting area has greatly been facilitated by the IASB-FASB convergence project to the extent that these bodies have been quite successful at eliminating differences between the two standards. For example, both IFRS and US GAAP require that

\footnotetext{
${ }^{2}$ Fajardo and Merrill, Alternative Methods of Incorporating International Financial Reporting Standards (IFRS) into the Accounting Curriculum. Journal of American Academy of Business", Vol 16, Num. 1. 2010.
} 
mergers/acquisitions be accounted for using the acquisition method, both have a fair value option, and both require that goodwill be tested at least annually for impairment. Of course, differences remain in the application of the respective standards, but such differences can be expediently addressed in this course. However, like the stand-alone approach, limiting IFRS to intermediate accounting and/or advanced accounting ignores the needs of nonaccounting majors who, as future business executives, require a general understanding of financials based on global reporting standards. Another disadvantage is that faculty is already burdened with having to cover an expanded body of US GAAP standards. Having to cover IFRS along with US GAAP in two three-credit, or even three three-credit hour courses, may cause intermediate accounting to devolve into a superficial content learning experience, characterized by rote memorization and cookbook problem-solving.

\section{INTEGRATING IFRS ACROSS THE ENTIRE CURRICULA}

Three features of IFRS, vis a vis US GAAP, are noteworthy. First, principles-based IFRS is strongly wedded to its theoretical framework. As mentioned above, under IFRS, the framework is considered to have the same authoritative support as the specific IASs and IFRS standards. This support contrasts with US GAAP, which relegates its Statements of Financial Accounting Concepts to a lesser authority. In fact, a major part of IFRS standard setting process involves vetting individual standards against the backdrop of how well they support the substance and spirit of the relevant framework concept. Rather than force adherence to a rigid set of prescribed rules and "bright lines", IASB allows considerable flexibility to the practitioner in evaluating how to apply particular standards. For example, most IAS and IFRS provide for alternative treatments, the selection of which is influenced by the nature and circumstances surrounding a transaction. Thus, IFRS standards consume much less paper space than their US counterpart. Second, while both regimes have similar objectives concepts, IFRS differs from US GAAP in terms of the greater emphasis that the former places on providing the user with financial statements and related footnotes that allow him/her to make optimal decisions. The use of accounting information for decisionmaking assumes a greater importance under IFRS than the stewardship and attests objectives of financial reporting. Third, the emphasis that IFRS places on assigning balance sheet elements (i.e., assets/liabilities) values reflective of their economic utility contrasts with the continued importance afforded the income statement over the balance sheet under US GAAP.

Reflection on these three features that differentiate US GAAP from IFRS suggests a more optimal approach in determining how best to incorporate IFRS into US accounting programs and curricula. That approach would be to integrate IFRS across the entire accounting curricula and to build an accounting program based on principles and oriented to the needs of decision-makers. Under an integrated approach, the introductory accounting courses would expose all business students to IFRS, the institutional and cultural factors underlying their development, differences between principles and rules-based reporting regimes, and the information needs of various users of accounting information. The first course might be oriented more toward financial accounting, but given the IFRS emphasis on the user of financial information, some traditional managerial/cost concepts might be covered contemporaneously. A second required introductory course might consist of traditional accounting topics (e.g., cash and receivables, inventory, etc.) but could be approached in a more conceptual manner. Each specific accounting topic might be mapped into a relevant framework concept. Specific IFRS and US GAAP standards could then be examined from the standpoint of the relevant concept. A possible organizational approach might be to discuss each accounting topic in terms of objective, measurement, and disclosure principles underlying financial events. IFRS and US GAAP could be explained in terms of how either or both comport with the relevant framework concept. Here the use of short cases might be utilized which force students to evaluate the suitability of an IFRS standard against the backdrop of the conceptual framework. In an information systems course, emphasis might be placed on understanding how electronic databases might be adapted to accumulate IFRS data and processing. Here, XBRL - a tagging system for transmitting financial data on annual 10Ks to the SEC - might be discussed. Under the integrated approach to IFRS incorporation, all business students would be required to take these three courses.

An efficient approach to integrating IFRS into the intermediate accounting series while covering traditional US GAAP standards might be to build accounting topics cash, inventory, etc. around business activities using a flow of funds model. Here, each topical coverage could be discussed in terms of decision-making as it affects operating, investing, and financing activities. Again, a case approach might be utilized and a set of questions facing decisionmakers could be developed in order to require students to evaluate and discuss how the decisions might be affected 
by differences between IFRS and US GAAP. Since US GAAP and IFRS standards have been largely converged, the merger and acquisition accounting course (i.e., advanced accounting) could merely supplement existing coverage with a discussion of differences between both regimes. In addition to covering traditional cost/managerial concepts, the cost/managerial course (for accounting majors only) might incorporate IFRS by considering how this reporting regime might increase/decrease tendencies toward income smoothing, big baths, and other agency problems, as well as consider the impact of IFRS on performance analysis and performance-based compensation. Discussion of IFRS in the auditing course might focus on how the principles-based nature of IFRS could affect an accountant's legal liability, the scope of the audit, and the auditor's liability under Sarbanes-Oxley (SOX), particularly the internal control provisions of the Act. Finally, the tax courses might examine how income could increase or decrease under IFRS, although the possible impact on the tax liability will depend on whether and to what extent existing tax laws will be affected.

There are, no doubt, many different ways of integrating IFRS across the curricula. However, such integration, regardless of manner or form, must provide students with a unifying theoretical structure - one which emphasizes the principles-based nature of IFRS. An integration of IFRS across the entire curricula will enable students to better synthesize and reinforce IFRS concepts and their application and to better contrast them with US GAAP. Moreover, an integrated approach to IFRS coverage, built around a conceptual framework requiring students to justify particular accounting treatments in a given set of circumstances, will transform accounting education from one of passive to one of active learning. Students will learn in an environment where the development of critical thinking, communication, written, and leadership skills are the norm rather than the exception. The principal disadvantage of integrating IFRS across the curricula is the required investment of time and money. Admittedly, in these difficult political and economic times, educators and administrators struggle with constrained budgets and limited resources. In this respect, accounting programs will be in active competition with other university programs for scarce funds, and accounting educators are currently grappling with how to cover an already mammoth body of knowledge. Thus, incorporation of IFRS utilizing any of the above approaches, particularly the third one, will be a hard sell.

\section{SUMMARY AND CONCLUDING COMMENTS}

Soon the Securities and Exchange Commission (SEC) will require all listed firms to submit financial statements prepared in accordance with IFRS. While the Big 4 international accounting firms have initiated major efforts to provide educational materials and support relating to IFRS, accounting educators have done little to address the question of how to incorporate this financial reporting system into their curriculum. For example, KMPG provides a webpage devoted entirely to IFRS (i.e., KPMG IFRS institute). This webpage provides IFRS information through web and podcasts, seminars, and professional, as well as academic articles. It is likely that FASB -IASB convergence efforts will continue subsequent to the mandatory adoption date. Given this likelihood, both sets of reporting standards are likely to be permitted for $10 \mathrm{~K}$ filings with an eventual transition to IFRS. Thus, accounting programs will be obliged to expose the students to both reporting regimes. Accounting educators will have to address the question of how to incorporate IFRS into the accounting curricula at a time of tight budgets, of limited faculty knowledge and experience with international standards, and a general aversion toward change of any kind. While the challenge to the academic community will be daunting, accounting educators will be required to provide a plan for incorporating the new reporting regime into existing coursework. Accordingly, this paper offers three approaches for such incorporation: 1) a stand-alone course, 2) integration into all upper-division financial accounting courses, and 3) integration across the entire accounting curricula. Reflection on the pros/cons of each approach suggests that the third alternative would be most desirable. Integration across the entire accounting curricula would first expose all business majors to the new reporting system; second, it would facilitate a better understanding of a principles-based accounting system and how it differs from the current rules-based US GAAP approach; and, third - perhaps its principal benefit, it would provide the basis for development of an accounting program centered around a unifying theoretical structure - in essence, a principles-based program. Such a program could lead to an interactive learning environment that emphasizes student development of critical thinking, communication, and interpersonal skills. 


\section{AUTHOR INFORMATION}

Robert Singer is an Associate Professor of Accounting of the School of Business and Entrepreneurship at Lindenwood University located in St. Charles, Missouri. He teaches advanced, cost/managerial, and international accounting at both undergraduate and graduate levels. His research interests include the effect of cultural and institutional factors on accounting conservatism, and the impact of mandatory adoption of IFRS in the US on financial reporting, and accounting education. E-mail: rsinger@lindenwood.edu 
NOTES 